\title{
OPINI MASYARAKAT DESA KERTOSARI JEMBER SEPUTAR PERUBAHAN TEMPAT PENGOLAHAN AKHIR SAMPAH (TPA) MENJADI OBJEK WISATA EDUKATIF
}

\author{
Ana Swandayani, Juariyah \\ Program Studi Ilmu Komunikasi, Fakultas Ilmu Sosial dan Ilmu Politik \\ Universitas Muhammadiyah Jember \\ Jl. Karimata No. 49 Jember \\ e-mail : Wandaaswa30@gmail.com
}

\begin{abstract}
This study aims to describe the Opinion of the Village Community of Kertosari Jember Regarding Changes in the Final Waste Management Site (TPA) into Educational Tourism Objects by using a type of qualitative research through a descriptive approach obtained from primary and secondary data through observation, interviews and documentation using the data analysis model Miles and Huberman with steps Data Collection, Data Reduction, Data Presentation, and Data Verificationdone in a way to get the actual data.In this study it was found that public opinion and visitors were positive and negative. The positive thing is that some of them agree with the TPA change to become a tourist attraction because it has benefits for the surrounding community and visitors who come for example as a place to take pictures,educational sites such as learning waste processing, recycling waste, making compost, and making methane gas. The negative thing about odors that interfere with breathing causes the health of the community to be disturbed, especially young children, and polluted river water due to the presence of rubbish deposits. From this it can be concluded that the surrounding community was disturbed by the pungent odorin the village and the water that becomes cloudy, this can be overcome by communication between the landfill manager and the surrounding community so that the community feels comfortable with the TPA in the village.
\end{abstract}

Keywords: Community Opinion, Waste Final Processing Site (TPA), Educational Tourism.

\begin{abstract}
Abstrak
Penelitian ini bertujuan mendejurnalkan tentang Opini Masyarakat Desa Kertosari Jember Seputar Perubahan Tempat Pengolahan Akhir Sampah (TPA) Menjadi Objek Wisata Edukatif dengan menggunakan jenis penelitian kualitatif melalui pendekatan deskriptif yang diperoleh dari data primer dan sekunder melalui observasi, wawancara dan dokumentasi dengan menggunakan model analisis data Miles and Huberman dengan langkah-langkah Pengumpulan Data, Reduksi Data, Penyajian Data, Dan Verifikasi Data yang dilakukan dengan cara guna mendapatkan data yang aktual. Dalam penelitian ini ditemukan bahwa opini masyarakat dan pengunjung ada yang berpendapat positif dan negatif. Hal positifnya beberapa dari mereka setuju dengan perubahan TPA menjadi objek wisata karena memiliki manfaat bagi masyarakat sekitar dan pengunjung yang datang misalnya sebagai tempat berfoto, tempat edukasi seperti belajar pengolahan sampah, daur ulang sampah, pembuatan kompos, serta pembuatan gas methan. Hal negatifnya bau yang mengganggu pernafasan menyebabkan kesehatan masyarakat terganggu terutama anak kecil, sertaair sungai yang tercemar akibat adanya endapan sampah. Dari sini dapat disimpulkan bahwa masyarakat sekitar merasa terganggu dengan bau menyengat di desa
\end{abstract}


tersebut serta air yang berubah tercemar, hal tersebut dapat diatasi dengan adanya komunikasi antara pihak pengelola TPA dengan masyarakat sekitar sehingga masyarakat merasa nyaman dengan adanya TPA didesa tersebut.

Kata Kunci: Opini Masyarakat, Tempat Pengolah Akhir Sampah (TPA), Wisata Edukatif.

\section{Pendahuluan}

\section{Latar Belakang Masalah}

Indonesia merupakan salah satu negara dengan jumlah penduduk sangat banyak, perkembangannya meningkat dari tahun ke tahun. Menurut data Menteri Dalam Negeri RI Tjahjo Kumolo, jumlah penduduk Indonesia per 30 Juni 2016 sebanyak 257.912.349 jiwa dengan jumlah wajib KTP per 31 Desember 2015 yakni 182.588.494 jiwa sedangkan pertumbuhan penduduk Indonesia masih di angka 1,49 persen. Hal tersebut mengakibatkan jumlah penduduk terus meningkat, sehingga keterbatasan lahan untuk menampung sisa konsumsi menjadi salah satu faktor penyebab volume sampah terus menggunung. Salah satu Kota dengan jumlah timbunan sampah terbanyak adalah Jember, merupakan wilayah kabupaten dengan jumlah penduduk pada tahun 2016 sebesar 2.419.000 jiwa, produksi sampah di kota ini terbilang besar dan meningkat hingga kini mencapai 1.300 meter kubik. Penanggulangan serius sangat dibutuhkan untuk mengatasi produksi sampah yang menjadi faktor pencemaran lingkungan akhirnya akan menyebabkan kerusakan lingkungan. Peristiwa tersebut menimbulkan masalah yang mengkhawatirkan karena terkait dengan lahan yang semakin sulit, pencemaran lingkungan serta timbulnya penyakit sehingga menimbulkan pendapat masyarakat yang menganggap sampah sebagai barang tidak bernilai sama sekali, hal tersebut dapat mempengaruhi perilaku masyarakat dalam membuang sampah dengan memisahkan antara sampah organik dan anorganik yang menunjukkan ketidakpedulian masyarakat terkait sampah. Paradigma lama yang masih banyak dianut yaitu sampah harus secepatnya dikumpulkan, diangkut dan dibuang ke Tempat Pengolahan Akhir Sampah (TPA) (Effendy, 2011:22).

Salah satunya TPA yang ada di Kabupaten Jember yang lokasinya di desa Kertosari Kecamatan Pakusari, dengan luas 6,8 Ha, dibagi menjadi 13 kavling merupakan satu-satunya TPA berada di dalam kota, dibangun sejak tahun 1992 yang dikoordinatori oleh staf kebersihan Dinas Lingkungan Hidup (DLH) Kabupaten Jember, R.M. Masbut memiliki rencana untuk menjadikan TPA ini 
sebagai tempat wisata lokal bagi warga Jember dan sekitarnya menjadi tempat beragam wisata edukasi yang ditawarkan, seperti pengolahan sampah menjadi gas methan, bank sampah, dan pengolahan sampah organik. Akan tetapi, sebagian masyarakat ada yang berpendapat positif dan negatif dengan adanya perubahan TPA menjadi objek wisata edukatif. Menurut Cutlip dan Center dalam Sastropoetro (1987:69) Opini publik memiliki kekuatan melalui individuindividu yang harus dipersuasi dan diorganisasikan yang memiliki 4 unsur yaitu: a) adanya masalah atau situasi yang sifatnya kontroversi, b) adanya publik yang secara spontan tertarik pada masalah tersebut, sehingga berusaha menyampaikan pendapatnya, c) adanya kesempatan untuk bertukar pikiran dalam kondisi tersebut, serta d) adanya interaksi dari individu-individu yang menghasilkan suatu pendapat yang sifatnya kolektif, artinya dapat diterima oleh individuindividu lain. Sedangkan pengertian wisata berdasarkan UU RI No. 10 Tahun 2009 adalah kegiatan perjalanan yang dilakukan baik perorangan maupun kelompok untuk mengunjungi destinasi tertentu dengan tujuan rekreasi, mempelajari keunikan daerah wisata, pengembangan diri dan sebagainya dengan kurun waktu yang singkat.

Berdasarkan latar belakang yang dikemukakan di atas, penulis terdorong untuk melakukan penelitian dengan judul “Opini Masyarakat Desa Kertosari Jember Seputar Perubahan Tempat Pengolahan Akhir Sampah (TPA) Menjadi Objek Wisata Edukatif."

\section{Rumusan Masalah}

Dari permasalahan di atas, peneliti tertarik untuk meneliti masalah yaitu :

1). Bagaimana pendapat opinion leader dengan adanya perubahan TPA yang menjadi objek wisata edukatif ?

2). Bagaimana pendapat pengunjung dengan adanya perubahan TPA menjadi objek wisata edukatif?

\section{Tujuan Penelitian}

Berdasarkan rumusan masalah diatas, tujuan yang ingin dicapai dalam penelitian ini yaitu :

1). Untuk mengetahui pendapat opinion leader dengan adanya perubahan TPA yang menjadi objek wisata edukatif.

2). Untuk mengetahui pendapat pengunjung dengan adanya perubahan TPA yang menjadi objek wisata edukatif.

\section{Tinjauan Pustaka}

\section{Teori S-O-R}

Teori yang digunakan dalam penelitian ini yaitu teori S-O-R (Stimulus- 
Organism-Respons) yang berasal dari ilmu psikologi, memiliki unsur-unsur sebagai berikut 1) pesan (stimulus) dimana stimulus yang disampaikan komunikator kepada komunikan berupa tanda atau lambang. 2) komunikan (organism) merupakan apa yang disampaikan komunikator kemudian komunikan menerima, memperhatikan, kemudian komunikan mencoba untuk mengartikan dan memahami pesan tersebut 3) efek (respons) yaitu dampak komunikasi berupa opini atau tanggapan yang muncul ketika pesan sudah diterima oleh komunikan.(Sumber,Effendy,1993:25)

\section{Kerangka Pemikiran}

Dalam penelitian ini kerangka pemikiran yang dihasilkan yaitu Tempat Pengolahan Akhir Sampah (TPA) yang dikelola oleh Dinas Lingkungan Hidup (DLH) yang dikoordinatori oleh staf kebersihan bapak R.M. Masbut dengan menggunakan teori Stimulus-OrganismRespons (SOR) dimana stimulus yaitu pesan yang disampaikan DLH kepada masyarakat/pengunjung sebagai komunikan kemudian komunikan menerima pesan sebagai informasi, jadi komunikan akan memperhatikan setiap pesan yang disampaikan selanjutnya komunikan mencoba/memahami pesan yang disampaikan komunikator.
Kemudian efek tersebut membentuk suatu opini atau tanggapan masyarakat/pengunjung yang kemudian menjadikan Tempat Pengolahan Akhir Sampah menjadi Objek Wisata Edukatif.

\section{Metode Penelitian}

\section{Jenis Penelitian}

Jenis penelitian yang digunakan adalah kualitatif, dimana prosedur penelitian yang menghasilkan data deskriptif berupa kata- kata tertulis atau lisan dari orang - orang dan perilaku yang dapat diamati, digunakan untuk mendapatkan data yang mendalam. (Sugiyono, 2017:9).

Sedangkan menurut Kriyantono (2006:58) menjelaskan pendekatan ini bertujuan menjelaskan fenomena dengan sedalam-dalamnya melalui pengumpulan data sedalam-dalamnya. Dari pemaparan diatas maka dapat disimpulkan bahwa penelitian deskriptif kualitatif adalah penelitian dengan tujuan menganalisis, mengidentifikasi, menjelaskan dan menggambarkan subjek penelitian.

\section{Lokasi Penelitian}

Penelitian dilakukan di Kabupaten Jember bertempat di Tempat Pengolahan Akhir Sampah (TPA) yang lokasinya berada di desa Kertosari Kecamatan Pakusari. Peneliti memilih Kabupaten ini dengan alasan karena merupakan salah 
satu daerah yang sedang menghadapi permasalahan sampah, namun dalam pengelolaan sampahnya baik dalam kebersihan serta pengelolan lingkungan perkotaannya dapat dikatakan sudah berhasil jika dibandingkan dengan kotakota yang ada disekitarnya. Hal ini dapat dibuktikan dengan didapatkannya penghargaan piala Adipura pada tahun 1993-1997.

\section{Sasaran Penelitian}

Sasaran penelitian ini yaitu opinion leader dan pengunjung yang datang ke lokasi wisata edukatif tersebut.

\section{Teknik Pengambilan Sampel}

Teknik pengambilan sampel yang digunakan adalah Accidental Sampling dan Purposive Sampling. Accidental Sampling adalah penentuan sampel tanpa sengaja dengan mengambil sampel yang ditemuinya pada saat itu atau selama bulan Desember-Februari yangdigunakan saat pengunjung ramai datang ke lokasi wisata. Sedangkan penelitian Purposive Sampling bertujuan memilih orang yang diseleksi berdasarkan kriteria-kriteria tertentu berdasarkan tujuan penelitian yaitu:

1) Tokoh masyarakat (opinion leader) di sekitar wilayah TPA Pakusari diantaranya:
a) Pemerintah setempat
b) Tokoh agama
c) Petugas kesehatan

d) Orang yang disegani

2) Masyarakat yang tinggal disekitar wilayah TPA Pakusari lebih dari 10 tahun.

\section{Sumber Data Penelitian}

Penelitian ini sumber data yang digunakan adalah data primer dan data sekunder yaitu:

1) Data primer adalah data yang diperoleh dari pengumpulan berbagai informasi dari informan dan catatan kondisi lapangan yang diperoleh melalui pengamatan peneliti secara langsung. Sumber data pertama dalam penelitian ini yaitu Opinion Leader dan pengunjung yang berada di lokasi TPA Pakusari, sebagai data pelengkap informan yang lain yaitu pihak pengelola TPA Pakusari atau Objek Wisata Edukatif.

2) Data sekunder adalah data yang diperoleh dari sumber kedua baik berupa study kepustakaan, literatur internet, dokumen/arsip dan publikasi yang berkaitan erat dengan permasalahan yang diteliti dengan tujuan untuk mendapatkan konsep-konsep, teori-teori, pendapat serta dokumen atau arsip yang dianggap penting. Dalam penelitian ini yang menjadi sumber kedua yaitu, Rencana Kerja Dinas Lingkungan Hidup, Masterplan Dinas Lingkungan Hidup dan lain-lain. 


\section{Teknik Pengumpulan Data}

Teknik pengumpulan data yang digunakan adalah:

1) Metode observasi, yaitu melakukan pengamatan langsung dan tidak langsung mengenai keadaan serta kondisi guna mendapatkan data.

2) Metode wawancara, dalam penelitian ini peneliti melakukan wawancara dengan membuat pedoman wawancara yang berupa pertanyaan tertulis atau pedoman diinginkan dalam wawancara.

3) Metode dokumentasi, dalam penelitian ini dokumen yang digunakan berbentuk gambar seperto foto, serta dokumentasi yang berbentuk tulisan antara lain, seperti: 1) Rencana Kerja Tahun 2017 Dinas Lingkungan Hidup Kabupaten Jember; 2) Masterplan Dinas Lingkungan Hidup dan 3) Referensi lainnya seperti Buku, skripsi, Tesis, dan skripsi-skripsi terdahulu.

\section{Metode Analisis Data}

Metode analisis data yang digunakan menggunakan Model Miles and Huberman yang menjelaskan bahwa aktivitas dalam analisis data kualitatif dilakukan secara interaktif dan berlangsung secara terus menerus sampai tuntas, sehingga datanya sudah jenuh. (Sugiyono, 2017:246). Langkah-langkah analisisnya yaitu:
1). Pengumpulan data (Data Collection), yaitu pengumpulan data di tempat penelitian dengan melakukan kegiatan observasi, wawancara, dan dokumentasi dengan menentukan strategi pengumpulan data yang tepat.

2). Reduksi data (Data Reduction), data yang diperoleh dari lapangan cukup banyak maka perlu dicatat secara teliti dan rinci yang artinya merangkum.

3). Penyajian data (Data Display), yaitu dengan menyajikan data akan memudahkan memahami apa yang terjadi selama penelitian berlangsung.

4). Verifikasi data (Conclusions Drawing/Verification), yaitu langkah terakhir dalam teknik analisis data yang dilakukan apabila kesimpulan awal yang dikemukakan masih bersifat sementara, dan akan ada perubahan apabila ditemukan bukti-bukti yang kuat atau dapat dipercaya.

\section{Hasil Penelitian dan Pembahasan}

Pendapat Opinion Leader Dengan Adanya Perubahan TPA Menjadi

\section{Objek Wisata.}

Opinion leader dalam penelitian ini memiliki kriteria yaitu orang yang disegani serta yang sudah tinggal di TPA lebih dari 10 tahun. Menurut P.S (58) berpendapat bahwa: 
"Dengan adanya perubahan TPA menjadi objek wisata biasanya oleh anak-anak disekitar sini dijadikan tempat foto/selfie. Biasanya hari libur itu ramai. Tapi untuk negatifnya mungkin bau itu yang masih mengganggu masyarakat disini, juga air yang awalnya bersih dan dapat sehari-hari sekarang sudah tercemar dampak pembuangan sampah di TPA. untuk masyarakat disini,TPA ini tidak memiliki manfaat." (sumber, wawancara tanggal 28/02/2019)

Pendapat yang sama juga disampaikan ibu MH (21), berpendapat bahwa :

"Positifnya daerah disini bisa dijadikan tempat wisata karna dulunya tidak ada tempat wisata di daerah sini. Negatifnya baunya tidak seperti yang dulu. Pendapat saya bagus jika TPA dijadikan objek wisata jadi bukan cuman TPA saja jadi ada peningkatan untuk kedepannya. Manfaatnya juga bisa dijadikan tempat berjualan untuk pedagang sekitar/mencari nafkah."(sumber, wawancara tanggal 28/02/2019)

Jadi, dari beberapa pendapat opinion leader diatas dapat disimpulkan bahwa opini atau pendapat masyarakat berkaitan dengan perubahan Tempat Pengolahan Akhir Sampah (TPA) ada yang berpendapat positif dan ada yang berpendapat negatif. Positifnya sebagian dari pendapat diatas berpendapat bahwa setuju dengan perubahan TPA menjadi objek wisata selain sebagai tempat untuk berfoto juga dapat digunakan sebagai tempat edukasi untuk anak usia dini, masyarakat dapat mempelajari cara pengolahan sampah, belajar mengenai sampah yang di daur ulang, belajar tentang cara pembuatan pupuk dari sampah, belajar mengolah sampah menjadi gas methan, serta dapat dijadikan tempat mencari nafkah untuk penjual atau pedagang makanan/minuman sehingga TPA yang dulunya sepi sekarang menjadi ramai karna banyaknya pengunjung yang datang ke TPA Pakusari. Sedangkan negatifnya masalah bau yang menggangu kesehatan masyarakat karena polusi yang disebabkan sampah yang berasal dari TPA Pakusari. Selain itu, sampah tersebut juga menyebabkan air sungai menjadi keruh jadi tidak bisa digunakan oleh warga sekitar.

\section{Pendapat Pengunjung yang Datang ke Tempat Wisata}

Pendapat masyarakat sangat penting, hal tersebut dapat membantu agar objek wisata dapat berkembang dengan baik serta dapat muenambah jumlah pengunjung Semakin banyak pengunjung yang datang artinya tempat wisata tersebut unik dan sangat cocok untuk dijadikan 
tempat berkumpul, bersantai dengan keluarga. Menurut FR (21) salah seorang pengunjung yang datang ke objek wisata tersebut mengatakan bahwa :

"Saya sudah dua kali datang kesini, jika ada kesempatan lain waktu saya akan berkunjung lagi kesini. Saya sangat setuju jika TPA dijadikan objek wisata edukatif karena menurut saya itu bagus, yang awalnya TPA identik dengan tempat yang kotor, bau, kumuh, jorok dan lainnya sekarang diubah menjadi objek wisata seperti ini. Selain itu, sampah yang ada dapat digunakan sebagai bahan daur ulang. Jika tempat tinggal saya berada di dekat wisata ini saya senang, karena saya dapat membantu mengelola objek wisata ini agar semakin berkembang”. (sumber, wawancara tanggal 04/12/2018)

Pendapat lain juga disampaikan AS (17), bekerja sebagai karyawan yang sudah 3 kali datang ke objek wisata tersebut. Dia berpendapat bahwa :

"Tempatnya bagus, semakin kesini tempatnya semakin bagus. Awalnya kaget karena yang saya tahu TPA itu kan tempat pembuangan akhir sampai sini ya kaget ternyata semakin bagus. Semoga TPA di tempat lain bisa meniru TPA disini".(sumber, wawancara tanggal 28/02/2019)
Jadi kesimpulannya, bahwa pengunjung sangat senang dengan adanya objek wisata yang ada di TPA Pakusari ini. Pengunjung bisa menghabiskan waktunya untuk beristirahat dari pekerjaan seharihari karena di tempat wisata ini tidak dipungut biaya (gratis), terdapat spot foto yang bisa dijadikan tempat berselfie/berfoto untuk anak muda, sebagai tempat berkumpul dengan keluarga serta anak-anak sampai yang dewasa bisa mempelajari cara pengolahan sampah yang baik yang bisa dijadikan pupuk dengan membedakan sampah organik dan anorganik.

\section{Informasi Yang di Dapat Pengunjung} Mengenai Objek Wisata

Suatu objek wisata akan sagat cepat menyebarluas dengan adanya informasi secara face to face, selain itu melalui media juga dapat mengetahui informasi terupdate, baik melalui media sosial atau media massa. Akan tetapi, menurut FR (21) yang berpendapat bahwa tidak hanya melalui media HP saja yang efektif dalam menyebarkan suatu informasi. Seperti pernyataannya bahwa :

"Saya sendiri tahu informasi mengenai wisata ini dari teman. Awalnya saya menolak karena tidak ada pikiran kalau objek wisatanya akan sebagus ini, karena ini kan tempat pengelolaan akhir sampah 
tapi karena rasa ingin tau saya tinggi dan saya juga merasa tertantang untuk datang kesini akhirnya saya berkunjung kesini. Saya tertarik dengan area spot foto yang ada disini seperti balon udara, air terjun, bunga sakura yang sangat bagus untuk dijadikan background foto. saya ada keinginan untuk menyampaikan wisata ini terutama ke adik saya agar dia tau bahwa sampah dapat dijadikan bahan daur ulang."(sumber, wawancara tanggal 04/12/2018)

Pendapat yang sama juga disampaikan oleh MA (17), bahwa : "Tau informasi ini dari Facebook kemudiantanya tempatnya dimana. Sedangkan media yang bisa digunakan melalui media sosial seperti FB atau secara face to face." (sumber, wawancara tanggal 28/02/2019)

Dari kedua pendapat diatas dapat disimpulkan bahwa pengunjung yang datang ke tempat wisata di TPA Pakusari rata-rata mengetahui tempat wisata tersebut dari teman, google dan dari media sosial seperti Facebook (FB). Media sosial seperti FB memang sering digunakan saat ini baik anak muda maupun orangtua karena pendapat pengunjung yang datang ke tempat wisata biasanya di share ke $\mathrm{fb}$ sehingga pengunjung lain tertarik untuk datang ke TPA Pakusari. Pengguna fb saat ini juga sangat banyak. Informasi melalui face to face juga digunakan dalam penyebaran informasi ke teman, saudara, dan keluarganya.

Upaya yang Dilakukan Dinas

\section{Lingkungan Hidup.}

\section{Asal Pemikiran dibangunnya Objek}

\section{Wisata Edukatif}

Asal pemikiran dibentuknya atau dibuatnya suatu tempat sangatlah penting karena dapat menjadi asal mula dibentuknya suatu tempat. Hal tersebut disampaikan oleh Bapak R.Muhammad Masbut atau yang akrab dipanggil Pak Masbut, beliau adalah koordinator pengolahan sampah Dinas Lingkungan Hidup sekaligus yang mempunyai pemikiran dibentuknya objek wisata edukatif disini. Beliau mengatakan bahwa "Tempat pengolahan akhir sampah baru dirubah menjadi objek wisata sekitar tahun 2017, tujuannya agar masyarakat sekitar misalnya pelajar, mahasiswa, maupun yang mau belajar tentang pengolahan sampah senang dan betah berada di tempat pembuangan sampah yang identik dengan jorok, bau."(sumber, wawancara tanggal 04/12/2018)

Hal tersebut juga disampaikan oleh Bapak Totok (31) yang mengatakan bahwa :

"Awal pemikiran dibangunnya objek wisata ini karena, orang kan berpikir kalau 
TPA itu kumuh, bau, atau istilahnya jelek. Karyawan disini juga agar senang bekerja disini biar betah juga dengan suasananya, pengunjung yang mau belajar tentang sampah juga agar betah disini. Jadi yang semula pemikiran orang kalau sampah bau, kotor tenyata sampai sini asyik."(sumber, wawancara tanggal 04/12/2018)

Dari kedua pemaparan diatas dapat disimpulkan bahwa, objek wisata edukatif yang berasal dari tempat pengolahan akhir sampah ini dibangun karnasampah identik dengan bau, kotor dan jorok yang tidak disenangi siapa saja, dapat digunakan sebagai tempat belajar bagi masyarakat sekitar dan umum yang ingin mengetahui bagaimana cara pengolahan sampah yang benar, belajar membuat pupuk kompos, belajar mengenai gas methan, serta belajar mebuat sampah daur ulang. Selain itu, agar karyawan, masyarakat atau pengunjung yang datang kesini betah dan nyaman dengan suasana yang disediakan disini.

Penyebaran Informasi yang Dilakukan Pihak Pengelola Objek Wisata.

Penyebaran informasi harus dilakukan agar masyarakat mengetahui objek wisata yang masih belum banyak orang tahu. Penyebaran informasi dilakukan dengan berbagai cara misalnya melalui media massa. Hal tersebut juga dilakukan pihak yang mengelola objek wisata ini yaitu Dinas Lingkungan Hidup seperti yang disampaikan Bapak Totok (31) yang berpendapat bahwa :

"Media cetak (koran), youtube, televisi, google, radio. Semua media ikut membantu menyebarkan informasi. Awal mula media tahu objek wisata ini adalah melalui facebook berupa update yang di unggah pak Masbut atau teman-teman itu juga pengaruh awal." (sumber, wawancara tanggal 04/12/2018)

Berdasarkan pemaparan diatas, dapat disimpulkan bahwa pihak pengelola tempat pengolahan akhir sampah di Pakusari yang mengelola objek wisata edukatif dalam menyebarkan informasi melalui media cetak, media massa, media online dan media elektronik. Selain itu, penyebaran informasi secara face to face / tatap muka seperti yang dilakukan pemulung di TPA Pakusari yang ikut membantu menyebarkan adanya wisata di TPA Pakusari kepada siapa saja. Jadi, semua media ikut membantu menyebarkan informasi tersebut agar masyarakat dapat mengetahui objek wisata yang semakin populer, sehingga semakin hari jumlah pengunjung objek wisata di TPA Pakusari ini semakin meningkat. 


\section{Kesimpulan dan Saran}

\section{Kesimpulan}

Dari penjelasan diatas dapat dikelompokkan menjadi beberapa pendapat (postif dan negatif) dari adanya perubahan TPA menjadi objek wisata edukatif, yaitu :

Pendapat Positif :

a) TPA bisa dijadikan tempat wisata untuk masyarakat sekitar karena tidak dipungut biaya / gratis.

b) TPA bisa menjadi tempat mencari nafkah untuk masyarakat sekitar seperti berjualan makanan atau minuman. Selain untuk masyarakat, TPA juga bisa menjadi tempat mencari nafkah untuk para pemulung yang datang ke TPA Pakusari.

c) TPA bisa menjadi tempat edukasi/pembelajarancara pengolahan sampah, membedakan sampah organik dan anorganik, membuat pupuk kompos, membuat gas methan dari sampah, membuat kerajinan dari daur ulang sampah.

d) Pengunjung sangat senang dan nyaman berada di tempat wisata tersebut.

e) TPA Pakusari menyediakan fasilitas yang dapat digunakan pengunjung seperti tempat berfoto dan kantin.

Pendapat negatif:

a) Masyarakat sekitar TPA masih terganggu dengan bau sampah yang menyengat yang setiap sore masuk kerumah-rumah warga.

b) Masyarakat TPA juga mengeluh dengan air sungai yang tercemar akibat adanya endapan sampah yang bercampur dengan sungai warga sehingga tidak bisa digunakan untuk kebutuhan sehari-hari.

\section{Saran}

Saran yang dapat disampaikan peneliti terkait hasil dari penelitian ini dalam rangka mengetahui opini atau pendapat masyarakat sekitar dan pengunjung TPA terkait perubahannya menjadi obyek wisata edukatif, antara lain:

Untuk Dinas Lingkungan Hidup Kabupaten Jember (Pengelola TPA Pakusari)

1) Dinas Lingkungan Hidup terutama pihak pengelola TPA Pakusari seharusnya dapat menjalankan tugas serta fingsi secara maksimal sesuai yang direncanakan di dalam rencana kerja, serta dalam pelaksanaan perannya tidak hanya sekedar membuat kebijakan saja melainkan juga dapat menerapkan fungsi regulator/pengatur yang memiliki aturan misalnya tidak membuang sampah sembarangan, tetap menjaga kebersihan lingkungan sekitar, melayani pengunjung yang datang, serta memberikan fasilitas yang baik secara optimal baik dalam penegakan, pelayanan, dan fasilitator. 
2) Dinas Lingkungan Hidup terutama pihak pengelola TPA mengadakan agenda pertemuan dengan opinion leader atau pemuka pendapat yang ada disekitar wilayah TPA, kemudian membicarakan bagaimana perkembangan TPA ke depan sehingga masyarakat tidak merasa terganggu dengan bau sampah yang sampai sekarang membuat masyarakat tidak nyaman.

3) Pihak pengelola sebaiknya menambah dan meningkatkan fasilitas yang ada di sekitar tempat wisata sehingga pengunjung semakin betah untuk berada di tempat tersebut.

\section{Daftar Pustaka}

Effendy, Onong Uchajana. Ilmu, Teori, \&FilsafatKomunikasi. PT. Citra Aditya Bakti: Bandung.1993.

------, Ilmu Komunikasi. Teori \& Prakteknya, Remaja Rosdakarya: Bandung.2011.

Kriyantono, Rachmat. Riset Komunikasi, Kencana Prenada Media Group: Jakarta.. 2006.

Sastropoetro, Santoso. Pendapat Publik, Pendapat Umum, dan Pendapat Khalayak Dalam Komunikasi Sosial. CV Remadja Karya: Bandung. 1987. Sugiyono, Metode Penelitian. Pendekatan Kuantitatif, Kualitatif, dan R\&D..Alfabeta: Bandung. 2017. 